HARAWAY, Donna. O manifesto das espécies companheiras - Cachorros, pessoas e alteridade significativa. Trad. Pê Moreira. Revisão técnica e posfácio Fernando Silva e Silva. Rio de Janeiro: Bazar do Tempo, 2021, 184 p.

\title{
RESENHA DE O MANIFESTO DAS ESPÉCIES COMPANHEIRAS - CACHORROS, PESSOAS E ALTERIDADE SIGNIFICATIVA
}

\author{
Davi Alexandre Tomm (Doutor em Letras pela UFRGS)
}

tomm.davi@gmail.com

\section{Duas histórias}

Na França do século XIV, um cachorro foi testemunha de um crime e participou do julgamento por combate contra o homem que o próprio cachorro acusara de matar seu dono. O animal ficou dias ao lado do lugar onde seu dono havia sido enterrado em uma floresta até que a fome o impeliu de volta para a cidade, onde foi direto à casa de um amigo do falecido. Depois de alimentado, ele conseguiu convencer esse homem a segui-lo até a floresta, com puxões na barra do casaco. Descoberto o corpo, ainda faltava descobrir o assassino. $\mathrm{O}$ cachorro, que ficou com o amigo do antigo dono, era sempre dócil e gentil, mas toda vez que cruzava com Macaire na rua tornava-se raivoso e atacava o sujeito violentamente. O novo dono do cachorro desconfiou desse comportamento e relatou o fato às autoridades. A notícia chegou ao rei, que mandou trazer o cão até a corte. O animal comportou-se, como sempre, de modo obediente e dócil, até que viu entre as pessoas no salão o assassino e, novamente, atacou-o violentamente. O rei não teve dúvidas e ordenou o julgamento por combate, de acordo com as leis da época, quando se acreditava que a justiça divina atuaria, colocando seu escudo sobre o inocente e levando o criminoso à derrota ${ }^{1}$. O assassino, armado com um porrete, foi derrotado pelo cão que, conseguindo desviar dos golpes, atacou-o na garganta. Desesperado, o assassino confessou o crime e acabou sentenciado e morto por enforcamento (CHAMBERS, 2021).

\footnotetext{
${ }^{1} \mathrm{Na}$ época, os animais eram julgados segundo as leis humanas; os domésticos nas cortes criminais comuns, e sua sentença era a morte; os selvagens, nas cortes eclesiásticas, sendo suas sentenças o banimento e morte por exorcismo ou excomunhão.
} 
Mais de 8 séculos depois, em 2018, 800 cachorros robôs AIBO $^{2}$, da Sony, tiveram um funeral em um templo budista do Japão, todos eles com etiquetas com seus nomes e os nomes de seus donos. Os pets eletrônicos, lançados em 1999, pararam de ser produzidos em 2006, e os donos dos AIBOs, muito apegados a seus "animais de estimação", ficaram em choque ao saber que, sem a produção de novos modelos, também não haveria mais como consertar os antigos. Seus cães robôs estariam mortos, assim que parassem de funcionar. A comunidade dos donos de AIBOs começou a compartilhar dicas de como prover suporte a seus animais de estimação, e um ex-funcionário da Sony, então, abriu uma empresa que se especializou no conserto desses robôs. Os modelos mais antigos, que não tinham mais peças de reposição, serviram como "doadores de órgãos" para os modelos mais novos ${ }^{3}$. Para ajudar no processo de luto dos donos, a empresa conseguiu organizar os funerais, que ocorreram com os cantos tradicionais e a queima de incenso, exatamente como as cerimônias de humanos. Os funcionários da empresa de reparos participaram das cerimônias como substitutos das famílias dos cães robôs, e, como oferendas, colocaram alicates aos pés dos cães robôs no lugar das tradicionais frutas. O sacerdote líder do templo explicou que, para o pensamento budista, não há nada de errado em honrar objetos inanimados, pois tudo tem a natureza-Buda, e que mesmo os AIBOs sendo máquinas e não tendo sentimentos, eles agem como um espelho das emoções humanas (BURCH, 2021).

\section{Um segundo manifesto}

Essas duas histórias poderiam muito bem figurar no mais recente manifesto da bióloga e filósofa Dona Haraway, O manifesto das espécies companheiras - Cachorros, pessoas e alteridade significativa. Elas trazem fatos que mostram algumas das questões com as quais Haraway se preocupa nesse texto, que é, antes de tudo, uma introdução ao seu novo plano de trabalho. A principal delas talvez seja a constituição de um pensamento relacional, que rompa com as categorizações, as tradicionais classificações do pensamento científico moderno, focando nas relações, múltiplas interferências, sobreposições, simbiogêneses entre natureza e cultura que ela designa através do signo "natureza-cultura". Essas duas histórias podem soar

\footnotetext{
${ }^{2}$ Artificial Intelligent Robot [Robô de Inteligência Artificial]. Desenvolvido para ter movimentos fluídos, ter uma sequência de simulação de travessuras, ter a capacidade de ser treinado e abanar sua cauda. Além do comportamento típico de cachorros, ele também era programado para certos comportamentos tipicamente humanos, como dançar e, em modelos mais avançados, até mesmo falar.

${ }^{3}$ Um dos funcionários da empresa afirmou que os donos dos cães robôs falavam dos problemas em termos de "juntas doloridas", o que o fez perceber que eles não viam ali peças de um equipamento eletrônico.
} 
estranhas se pensarmos a partir das formas tradicionais da nossa epistemologia moderna ocidental. Como lidar com categorias como robô, cachorro, humano, testemunha, doador de órgãos, que marcam a linguagem e a carne nessas histórias? Se pensarmos com Donna Haraway, no entanto, podemos nos ater com mais atenção aos modos como nosso mundo se constitui não a partir de categorias monolíticas e essencialistas de identidades, tipos, gêneros, espécies, mas sim a partir das constantes trocas que ocorrem nas relações mútuas entre diferentes espécies, não só espécies biológicas, mas espécies de coisas. As espécies companheiras desse novo trabalho e os ciborgues do seu primeiro manifesto servem justamente para apagar as fronteiras, e, nas palavras da autora, pretendem informar sobre políticas e "ontologias vivíveis" para os "mundos de vida de hoje" (HARAWAY, 2021, p. 12). Trata-se de um projeto amplo, ou, como ela mesma defende, trata-se de se ater à complexidade. Nesse novo caminho, no entanto, no mundo do "canil", ela não está sozinha, mas segue o caminho com vários companheiros de pensamento, nas ciências naturais e humanas da contemporaneidade, e que tem como foco principal pensar não mais em termos de sujeitos, mas de mundos: mundos vivíveis, mundos possíveis.

O novo manifesto de Haraway foi publicado originalmente em 2003, quase trinta anos após o Manifesto ciborgue, que a fez despontar no centro dos debates nas áreas das ciências humanas, especialmente na teoria feminista. $\mathrm{O}$ atual manifesto é dividido em cinco capítulos, sendo o primeiro uma grande introdução teórica e apresentação dos principais conceitos e das questões que estarão em jogo no "nascimento do canil" (HARAWAY, 2021, p. 13). Os quatro capítulos subsequentes são todos "histórias" - de evolução, amor, adestramento e raça - e focam antes de tudo na narrativa, deixando de lado qualquer pretensão a análises e explicações.

Nesse sentido, esse segundo manifesto tem uma grande diferença para com o primeiro: os conceitos e questões teóricas apresentados no primeiro capítulo, intitulado "Naturezasculturas emergentes", não são retomados diretamente nos capítulos subsequentes para esclarecer, e serem esclarecidos, pelas histórias narradas. Com um estilo bem mais ensaístico que o primeiro manifesto, Haraway cumpre à risca o que ela afirma no início ${ }^{4}$ : “As notas [da filha de um jornalista esportivo] exigem que não haja nenhum desvio das próprias histórias animais. Lições devem ser parte inextricável da história” (HARAWAY, 2021, p. 25). É

\footnotetext{
${ }^{4}$ Haraway retoma sua criação católica e a convivência com seu pai, um jornalista esportivo, para se colocar como herdeira dessas duas instituições, a imprensa e a igreja, nas quais a crença moderna da irreconciliação entre história e fato não vingou.
} 
deixada ao leitor a tarefa de captar por conta própria as ideias do início que estão por trás das histórias de raças, de treinamentos, de criações - nos fatos que essas histórias narram.

Um manifesto, na verdade, não tem obrigação de se aprofundar teoricamente; ele é antes a apresentação da linha de pensamento a ser seguida em um projeto, uma proposição de novas questões a serem abordadas dali adiante. $\mathrm{E}$ isso seu texto faz muito bem, pois o que Haraway introduz aqui será tema de análises mais aprofundadas e trabalhadas em suas obras posteriores When Species Meet (2008) e Staying with the Trouble: Making Kin in the Chthulucene $(2016)^{5}$. Nesse sentido, a edição brasileira acerta em cheio ao acrescentar uma entrevista de Haraway com Nicholas Gane, pois ela ajuda bastante os leitores pouco familiarizados com a obra da autora, dando não só uma boa ideia do que significa a passagem de um manifesto a outro, mas também ampliando a reflexão da autora sobre as questões que está pensando no momento, citando outros nomes que se relacionam com sua obra e esclarecendo dúvidas sobre suas posições e ideias.

De um manifesto a outro, então, não há exatamente uma mudança de pensamento, ruptura ou giro epistemológico, mas um passo além. Sem abandonar a questão do biotecnopoder, Haraway começa a olhar agora com mais atenção para as espécies a partir de uma ideia de parentesco. "Fazer parentesco" é a expressão no título do seu livro mais recente e que aparece no Manifesto, e indica justamente essa nova perspectiva da filósofa. Trata-se de pensar em famílias não mais dentro da matriz tradicional de hereditariedade de genes que são passados diretamente, de genealogias em formas de árvores, mas das múltiplas relações possíveis das famílias multiespécies que se constroem a partir desse "fazer parentesco". Não mais as árvores genealógicas, mas um rizoma parental. É o que ela quer mostrar ao narrar as histórias das raças de cães, mostrando como no simples contato entre Cayenne e Donna uma miríade de conexões históricas, biológicas, naturais-culturais se entrelaçam: das migrações, das desapropriações de terras, dos extermínios de povos e do fim das culturas de fazenda, até os clubes de apreciadores de raças, as produções de raças puras, os atestados, genealogias, treinos e adestramentos. A questão é provocar uma mudança de olhar, ou melhor, um refinamento de nossa atenção, com a qual passamos a perceber o que está em jogo no simples fato de termos um cachorro de determinada raça, ou mesmo sem raça definida, em nossa casa - no meu caso, como pensar a minha relação com as duas gatas que estão agora dormindo, uma na cama e outra no sofá, e que, de manhã cedo, antes das sete, já me acordam para pedir

\footnotetext{
${ }^{5}$ Quando as espécies se encontram (ainda sem tradução para o português) e Permanecendo com o problema: fazer parentesco no Chthuluceno (uma tradução para o português está sendo feita pela editora n-1).
} 
ração, tornando-se meus despertadores naturais. Olhar para as histórias dessas relações é compreender como espécies e raças diferentes formaram umas às outras, através das múltiplas relações ao longo do tempo; as espécies companheiras se formaram mutuamente, nos encontros e desencontros trágicos ou felizes que as marcaram tanto no signo quanto na carne.

Para isso, é importante destacar que os cães, assim como os ciborgues, não são metáforas, não funcionam como alegorias ou como substitutos para falar de outra coisa ${ }^{6}$ : "Cães, em sua complexidade histórica, são importantes aqui [...]; são presenças carnais, materiais-semióticas, no corpo e na tecnociência" (HARAWAY, 2021, p. 14). As histórias que ela conta sobre a evolução dos cães, sobre a ideia do amor incondicional, sobre as técnicas de adestramento e sobre as raças servem para pensarmos os cães, com os cães, sobre eles e sobre nós, sobre as relações que construímos e que nos constituem. Contra a tendência antropomorfizante narcísica de nossa espécie, que cria "projeções perigosas e antiéticas", que transforma os cães domésticos em "crianças peludas", Donna Haraway defende que a beleza dos cães está em não ser um télos, uma projeção ou realização de um desejo; eles são "uma espécie em relação obrigatória, constitutiva, histórica e proteica com seres humanos" (HARAWAY, 2021, p. 20). Como qualquer relação, esta não é apenas agradável, mas cheia de eventos terríveis, de desperdícios e violências, de ignorâncias, mas também de alegrias, invenções, diversões, trabalho e inteligência. Para a filósofa, é importante aprender "como narrar essa co-história e como herdar as consequências da coevolução na natureza-cultura" (HARAWAY, 2021, p. 20). Seus quatro capítulos de histórias são exatamente essa tentativa de narrar e aprender, de deixar os fatos falarem e ensinarem por si.

\footnotetext{
${ }^{6}$ Essa é uma preocupação cada vez mais presente nas teorias contemporâneas, que rompem com aqueles antigos estudos sobre o comportamento animal que tentava entendê-los através dos nossos moldes de comportamento e de pensamento. Não se trata mais de testar a inteligência do macaco tentando ensiná-lo a fazer coisas humanas ou se comunicar através da linguagem dos animais, mas de entender a inteligência específica de cada ser de acordo com suas particularidades e suas interações com o seu meio, uma inteligência situada em mundos. Também aqueles teóricos que se voltam para a natureza para aprender questões essências para a nossa própria sociedade se afastam das perigosas projeções antropomórficas. Por exemplo, Brain Massumi, em $O$ que os animais nos ensinam sobre política, afirma que não se trata de encontrar uma política humana do animal, "mas uma política inteiramente animal, livre dos paradigmas tradicionais do sórdido estado de natureza e das pressuposições acerca dos instintos que permeiam tantas facetas do pensamento moderno" (MASSUMI, 2017, p. 11). O trabalho de Massumi, inclusive, não deixa de ser um companheiro do de Haraway, ambos informados pela mudança ocorrida nas ciências naturais, especialmente na biologia evolutiva, que passa a desconstruir a ideia de evolução baseada nos instintos de competição e sobrevivência, que pressupunha a agressão como comportamento dominante, mas sim na evolução a partir da simbiose, da colaboração mútua, que coloca a simpatia e criatividade no centro (MASSUMI, 2017). Para os dois autores, é de fundalmental importância os trabalhos desenvolvidos por Lynn Margulis.
} 


\section{Naturezas-culturas, espécies companheiras, simbiogêneses}

Simbiogênese é um conceito da biologia evolutiva que apresenta a evolução não mais como a narrativa do progresso das formas mais simples para as mais complexas, na qual as relações de competição e adaptação seriam dominantes, tendo no ser humano sua forma mais perto da perfeição; a ideia de simbiogênese mostra como a evolução da vida no planeta se deu por relações de ajuda mútua e como os organismos unicelulares foram os responsáveis pela formação de um ambiente propício para o surgimento de organismos mais complexos e formas de vidas maiores. A bióloga Lynn Margulis foi um dos nomes mais importantes desses estudos e é citada já nas primeiras linhas do manifesto de Haraway. Podemos dizer que o conceito permeia todo o texto, não só por causa das evidentes afiliações biológicas da autora com essa nova visão da evolução, mas também porque seu trabalho envolve uma simbiogênese entre diferentes áreas, diferentes discursos. Como já nos indica o título do primeiro capítulo "Natureza-cultura emergentes", trata-se de uma simbiogênese entre os dois domínios que organizaram o pensamento tipológico e dicotômico do Ocidente moderno. Haraway, como já havia feito no seu primeiro manifesto, coloca-se na posição que vem se tornando cada vez mais evidente a partir do final do século XX: a de mostrar as contaminações de fronteiras. Assim, a simbiogênese serve para evidenciar não mais os lugares estáticos, mas as relações que constroem identidades, sujeitos, discursos; as relações mútuas que criam histórias e naturezas-culturas. A simbiogênese está no próprio estilo da sua escrita, ao mesmo tempo poética e científica, narrativa e argumentativa - tudo isso - e também política.

A simbiogênese também pode significar o método interdisciplinar da filósofa, que se deixa infectar pelo pensamento de várias companheiras e companheiros teóricos, fazendo com que seu pensamento também se constitua no processo e nas relações. Um desses companheiros de pensamento de Haraway, Bruno Latour, já afirmara que a constituição moderna separou a natureza da cultura em dois domínios de saberes que não deveriam se misturar. Mas essa constituição estava baseada em uma relação sempre escorregadia entre os dois domínios, pois nossas relações com as coisas nunca foi estática, mas movediça (LATOUR, 2019). Nós tratamos nossos animais de estimação como membros de nossa família, não só chamando-os de filhos, como cuidando deles às vezes mais do que de nós mesmos. A herança medieval dos animais colocados no mesmo nível dos humanos perante o sistema legal-religioso continua a nos contaminar. Até mesmo os seres inanimados não 
escapam dessa forma de relação antropomorfizada. Basta lembrar de quantas vezes nós já nos irritamos com um computador ou com um celular que não funcionam direito a ponto de tratálos como uma pessoa que nos aborrece, xingando e maldizendo, como se isso fosse resolver o problema ${ }^{7}$. O caso dos donos dos cachorros robôs no Japão é apenas um exemplo de como essas relações são cada vez mais complexas e não cabem mais dentro das classificações tipológicas do pensamento científico tradicional.

O conceito de "natureza-cultura" de Donna Haraway significa exatamente isso: olhar para a relação entre sujeitos, sujeitos e objetos, sujeito e predicado; não se trata mais de entidades já prontas, com suas qualidades dadas exercendo sobre elas mais força de determinação do que as relações. De modo geral, os principais conceitos que ela maneja em seu manifesto apontam para essa direção: os seres se constituem um aos outros e a si mesmos nas suas relações, nas buscas por alcançar uns aos outros, através das "preensões" (HARAWAY, 2021, p. 15). Esse conceito retirado da filosofia do processo de Alfred North Whitehead significa um movimento fluido, anterior a qualquer captura, pois as preensões antecedem qualquer apreensão, compreensão e percepção, mas são exatamente o que dá as condições de possibilidade para estas. Preensões são as formas como as entidades se relacionam umas com as outras, entidades reais, ocasiões reais. Elas são uma forma básica do que constitui as entidades antes de serem as próprias entidades (WHITEHEAD, 1985).

Por isso, no seu projeto de resgatar uma filosofia do organismo, Whitehead afirma que a categoria da "relação" terá domínio sobre a da "qualidade" (WHITEHEAD, 1985). Uma entidade (pessoas e coisas) não é um bloco principal de essências definidoras revestido por camadas moventes qualitativamente secundárias. São antes as ocasiões de experiência que existem na realidade e formam as pessoas em um continuum de eventos sobrepostos. Essa visão requer não mais pensar em identidades definindo pessoas, mas pessoas definindo identidades $^{8}$. Essa base epistemológica da cosmologia de Whitehead é fundamental para o projeto de Haraway. Seu manifesto também quer romper com os determinismos biológicos e culturais, que enquadram os seres em categorias enfocadas nas qualidades, sem olhar para como estas se constituem nas relações complexas e constantes entre os diferentes seres com

\footnotetext{
${ }^{7}$ Nós já nem mesmo lembramos como essas relações contaminam a nossa linguagem. Por exemplo, a palavra "avião" vem do francês "avion", que significava "ave grande".

${ }^{8}$ A filosofia do processo de Whitehead vem justamente da crítica do filósofo ao que ele chama de "materialismo científico", a visão clássica da ciência moderna que reduz a realidade a configurações estáticas de uma matéria bruta irredutível, em que o fixo e imutável tem precedência sobre o fluxo contínuo (WHITEHEAD, 2006). Os conceitos "qualidade", "forma" e "matéria" são abstrações úteis, mas não descrevem o concreto da realidade, pois nenhuma entidade pode ser concebida de modo completamente abstrata do sistema do universo.
} 
que coabitamos o mundo: "Não existem sujeitos e objetos pré-constituídos nem fontes únicas, atores individuais ou finais definitivos" (HARAWAY, 2021, p. 15). Categorias como "natureza" e "cultura" não são estáticas, mas provisórias e locais: "Sujeitos, objetos, tipos, raças, espécies, estilos e gêneros são produtos das suas relações” (HARAWAY, 2021, p. 16).

Assim, os conceitos de "espécies companheiras" e de "alteridade significativa" engendram essa ideia das relações constitutivas, a partir do que a antropóloga Marilyn Strathern (outra companheira de pensamento citada por Haraway) chama de "conexões parciais": "padrões nos quais atores não nem todo nem parte" (HARAWAY, 2021, p. 17). As espécies companheiras formam um grande "bestiário de agências, tipos de relações e marcações de tempo" (HARAWAY, 2021. p. 15), em que é preciso pensar como seres tão diversos podem "seguir junt[o]s" (HARAWAY, 2021, p. 16). É um trabalho que busca levar a diferença a sério, um trabalho vulnerável, que mantém os pés no chão, pois não busca por respostas universais, transcendentes ao mundo real das experiências. A alteridade significativa pensada nessa prática quer dizer "agências e estilos de vida não harmônicos, responsáveis tanto por suas histórias díspares herdadas quanto por seu futuro comum - quase impossível, mas absolutamente necessário" (HARAWAY, 2021, p. 16). Por isso, os cachorros estão aqui como sujeitos, agentes dessa história contraditória de relacionamentos nos quais "nenhum dos parceiros preexiste à relação, e essa relação nunca está acabada" (HARAWAY, 2021, p. 20).

Seu manifesto foca nas histórias de cachorros que mostram essas relações, que levam à “implosão da natureza e da cultura na implacável e historicamente específica vida conjunta de cachorros e pessoas ligados em alteridade significativa" (HARAWAY, 2021, p. 24). Essas histórias nos "interpelam" ${ }^{9}$, pois são narrativas carregadas ideologicamente, que nos convocam a ser responsáveis com os regimes em que devemos viver com eles. Nós os convocamos para habitar os construtos de natureza e cultura, o que traz consequências de vida e morte, saúde e doença, extinção e longevidade. Mas as histórias também são maiores que as ideologias, e a esperança reside aí, pois nós também convivemos uns com os outros carnalmente, e as maneiras dessa coabitação carnal não foram esgotadas por nossas ideologias (HARAWAY, 2021). Através dessas histórias, Haraway quer convencer seu leitor de que, como "habitantes da tecnocultura, é nos tecidos simbiogenéticos da natureza-cultura que nos tornamos quem somos, nas narrativas e nos fatos" (HARAWAY, 2021, p. 24).

\footnotetext{
${ }^{9}$ Haraway toma o conceito de interpelação de Louis Althusser: "como sujeitos são constituídos a partir de indivíduos concretos ao serem 'convocados' pela ideologia a assumirem suas posições de sujeito no estado moderno" (HARAWAY, 2021, p. 25).
} 


\section{Histórias de relações}

As histórias narradas por Haraway nos quatro capítulos subsequentes tratam das relações em diferentes escalas de tempo-espaço; a evolução, o amor, o adestramento e as constituições das raças se desenvolvem através do tempo evolutivo dos cachorros e humanos como espécies; do "tempo presencial” (HARAWAY, 2021, p. 75) dos corpos mortais, das vidas individuais; e do tempo histórico das populações, regiões e nações. Essas escalas são também "coconstituídas por agências humana, animal e inanimada" (HARAWAY, 2021, p. 75). No capítulo "Histórias de evolução", ela busca "maneiras de chegar à coevolução e coconstituição sem retirar dessas narrativas suas brutalidades e belezas multiformes" (HARAWAY, 2021, p. 36). Trata-se de romper com as narrativas tradicionais, seja no âmbito científico ou popular, sobre o adestramento dos cães pelos humanos como mais um capítulo no mito do progresso, em que cachorros foram adestrados como ferramentas para ajudar no progresso da civilização. Passamos a ver os cães (mas também outras espécies) como tendo um papel de agente no processo de domesticação: primeiro, aproximando-se dos humanos, por interesses diversos próprios deles, para, depois, as duas espécies coreografarem "uma interminável dança de agências distribuídas e heterogêneas" (HARAWAY, 2021, p. 37). A coevolução e coabitação se complementam nessa dança, a domesticação é um processo de evolução mútua em que uma espécie se beneficia da outra. A coevolução significa mudanças biológicas nos animais e nos humanos - e nesses últimos as mudanças não são apenas culturais. A regra para essa complexa coreografia é a plasticidade, os organismos vivos integrados aos meios em que vivem processam informações ambientais e genéticas em todos os níveis, e é isso que determina o que eles se tornam.

Essa plasticidade orgânica não é apenas biológica, mas também se mistura com a cultura, é natural-cultural, pois a coevolução significa que os seres se misturam em relações e parcerias, simbiogêneses, que alteram suas carnes e seus signos. Em "Histórias de amor" e "Histórias de adestramento", cachorros e humanos são indivíduos nas suas relações mais pessoais, nas irredutíveis complexidades que envolvem uma verdadeira relação interespecífica, uma intersubjetividade real: "Intersubjetividade não quer dizer 'igualdade', um jogo literalmente mortal na cachorrolândia; ela quer dizer, sim, prestar atenção à dança conjunta de alteridade significativa cara a cara" (HARAWAY, 2021, p. 52). A relação com os cachorros é vista para além da crença do amor incondicional, segundo a qual pessoas cansadas de todas as dificuldades que envolvem as relações humanas encontram o consolo nesse amor 
incondicional dos cachorros e, em troca, amam-nos como filhos. É preciso vencer essa "neurose do narcisismo caninofílico" (HARAWAY, 2021, p. 43), que vê nos cachorros verdadeiros restauradores das almas atribuladas dos humanos. É preciso pensar em uma relação calcada no respeito, que busca o permanente conhecimento mais profundo do outro e aprende a lidar com os inevitáveis erros que surgem desse esforço. $\mathrm{O}$ amor deve ser aquele de conviver com uma espécie diferente da nossa e não o de transformar essa espécie em uma projeção de nossos desejos e necessidades. Viver em conjunto é respeitar o "cachorro integral" (HARAWAY, 2021, p. 45), ou seja, não apenas o meu cachorro, mas o cachorro como um tipo de uma raça ${ }^{10}$.

Por isso, é preciso também aprender as histórias das raças de nossos cachorros e o que elas significam, para que possamos respeitá-la e, assim, nos relacionar de modo mais integral com nosso animal de estimação. Isso implica também respeitar os cachorros por seus trabalhos, o que ajuda a manter viva a consciência da diversidade de espécies e de raças. As diferentes técnicas de adestramento, por exemplo, com seus aspectos positivos e negativos, tratam os cachorros como sujeitos com capacidades múltiplas, com diferentes interesses, com uma interioridade muito mais complexa do que aquela engendrada na visão romantizada do animal fofinho e dependente - cujo reducionismo e apagamento de diferenças constitutivas são tão perigosos quanto algumas das técnicas mais severas de adestramento (HARAWAY, 2021).

É muito importante também o que os adestramentos ensinam sobre a comunicação, um elemento essencial para as relações entre as espécies companheiras e para a constituição das alteridades significativas: “uma 'comunicação' que atravessa diferenças irredutíveis é o que importa. Conexões parciais situadas são o que importa; desse complexo jogo de cama de gato emergem juntos cachorros e humanos. O respeito está na base do jogo" (HARAWAY, 2021, p. 59). Encontrar uma linguagem comum é reconhecer que do outro lado sempre está alguém que escuta, e é preciso saber quem é esse que escuta. Não se trata obviamente de cair na antropomorfização perigosa de ver os cachorros como se eles pudessem falar, mas que eles podem se comunicar conosco de outros jeitos, do seu jeito ${ }^{11}$. Isso também ajuda a romper com

\footnotetext{
${ }^{10}$ Ela cita o trabalho de Linda Weisser, criadora de cães de montanha dos Pirineus e ativista da saúde da raça, que defende o amor com respeito, que implica aprender a cuidar da raça e não apenas do seu próprio cachorro. Por isso, ela recomenda, sem titubear, que um cachorro resgatado agressivo ou qualquer cachorro que morda uma criança seja morto, para que assim se salve a reputação da raça e a vida de outros cachorros - além da vida das crianças.

${ }^{11} \mathrm{O}$ cachorro da primeira história conseguiu se comunicar com o amigo do dono, puxando-lhe a barra do casaco, latindo e correndo na sua frente, para indicar o caminho até onde estava o corpo. Também se comunicou com o 
ideias perigosas por trás dos discursos mais radicais sobre os direitos dos animais, que acabam avaliando os bichos em escalas de similaridade com os humanos. Citando a criadora Vicki Hearne, Haraway apresenta a ideia dos direitos firmados na relação e não em categorias identitárias separadas e preexistentes: "no adestramento, os cachorros obtêm 'direitos' com humanos específicos" (HARAWAY, 2021, p. 63). Perguntar o que são os direitos dos animais é pressupor que estes existam em algum lugar e precisem ser descobertos ${ }^{12}$. Trata-se, então, de perguntar "como um ser humano entra em relação de direitos com um animal?" (HARAWAY, 2021, p. 63).

Na seção sobre a história do agility e sobre participação de Haraway nesse esporte com seus dois cachorros, fica ainda mais evidente a importância dessa comunicação que Hearne (apud HARAWAY, 2021, p. 63) chama de "cara a cara”. A comunicação entre condutor e cachorro no esporte se dá pela literalidade da carne, pela honestidade e coerência, com respeito mútuo, independentemente da diferença de espécie. É preciso encontrar a relação de confiança capaz de criar esse contato. Condutor e cachorro precisam se tornar "suficientemente coerentes em um mundo incoerente, a fim de se envolverem em uma dança conjunta do ser que cria respeito e resposta na carne, na corrida, no percurso. E, depois, lembrar de viver dessa maneira em qualquer nível, com respeito" (HARAWAY, 2021, p. 73).

\section{Tropos, metaplasmos, transfecção: carne e signo}

Copresença, coabitação, coevolução, cocriação... esses conceitos proliferam no texto de Haraway. Além de reforçarem a centralidade do pensamento relacional, mutual, eles também nos informam mais sobre essa importante ideia que ela apresenta no primeiro capítulo e que se repete como um refrão ao longo do texto: as histórias marcam os indivíduos não só na dimensão semiótica (da linguagem, dos discursos), como também na dimensão biológica (na carne, no DNA, nos genes). Já nas primeiras linhas, ela afirma que, se conferissem o DNA dela e de sua cachorra Cayenne Pepper, "encontrariam potentes transfecções" (HARAWAY, 2021, p. 9) nas duas. Conceito da microbiologia, a transfecção

rei e a corte através da sua brusca mudança de comportamento diante da aparição do assassino. Por outro lado, podemos pensar o que significa o fato de pessoas quererem um animal robô que podia até mesmo falar, ao invés de investir seu tempo e dinheiro em um animal biológico. O que esse fato nos ensina e nos informa sobre nosso tempo, nossas relações, sobre a história do capitalismo como formador de relações?

${ }^{12}$ Essa concepção de direitos dos animais não deixa de ter por trás a visão clássica de que existam entidades com identidades e qualidades fixas, fora do mundo das relações, e que, portanto, devemos procurar nessa esfera o que são seus direitos. 
nomeia um procedimento que introduz genes estranhos em células para a produção de células geneticamente modificadas. São transformações nas células por adição de um elemento, assim como a introdução do prefixo "co-" nas palavras acima poderia ser transfecções semióticas.

Não à toa Haraway afirma que suas histórias trafegam em tropoi, em figuras de linguagem necessárias para dizer qualquer coisa ${ }^{13}$. Seu tropos favorito é o "metaplasmo", que ela aproxima da biologia, por se parecer com termos como "protoplasma, citoplasma, neoplasma e germoplasma" (HARAWAY, 2021, p. 28, grifo da autora). O metaplasmo é um tropos que nos ajuda a entender melhor a evolução das línguas, pois se trata de mudanças nas palavras, através de adição, omissão, inversão ou transposições de letras, fonemas ou sílabas ${ }^{14}$. Ele mostra a natureza viva e sempre em movimento das línguas, suas mudanças na história, sua plasticidade, sua forma trôpega e desviante. Na sua etimologia, metaplasmos, no grego, significa "remodelar, reformar". Apesar de em termos gramaticais os metaplasmos não envolverem mudanças de significados nas palavras, o termo é usado, como bem nota a autora, para qualquer tipo de alteração nas palavras, sendo intencionais ou não. Os vários conceitos com o prefixo "co-" são metaplasmos, mas também a transfecção pode ser um metaplasmo: "uma substituição em uma linha de bases de um ácido nucleico pode ser um metaplasmo, mudando o significado de um gene e alterando o curso de uma vida" (HARAWAY, 2021, p. 28). O metaplasmo pode ser proposital, necessário ou pode ser também um erro, um tropeço, mas esse erro faz uma grande diferença carnal. Assim, as histórias de cachorros estão cheias de metaplasmos e transfecções, estão permeadas por mudanças, evoluções, tropeços, erros que marcam na carne e no código as espécies companheiras.

No último capítulo, "Histórias das raças", ela mostra como as formações de raças hoje tão conhecidas se deram pela coabitação de diferentes raças, da mistura de cães que vieram de povos migrantes e se juntaram aos cães das regiões nativas. Posteriormente, muitas dessas raças se tornaram admiradas por pessoas que criaram associações e passaram a estipular padrões de pureza ou mesmo fazer manipulações através de cruzamentos para aprimoramento de raças. As histórias de cachorros e humanos é cheia de metaplasmos, transfecções, tropeços,

\footnotetext{
${ }^{13}$ Ela retoma a etimologia da palavra, no grego, trópos, 'direção, giro', do verbo trépo, "desviar ou voltar-se", para enfatizar o caráter sempre desviante e trôpego da língua e romper com o mito de uma linguagem capaz de comunicar perfeitamente, sem ruídos, sem tropeçar.

${ }^{14}$ Por exemplo, em "stella", do latim, para "estrela", ocorre a prótese, acréscimo de fonema no início da palavra (e-); a epêntese, acréscimo de fonema no meio da palavra (r-); e síncope, queda de fonema no meio da palavra (l). Também podem ocorrer em casos de estrangeirismo: chic (francês) - chique e lunch (inglês) - lanche, em que temos o paragoge, acréscimo de fonema no fim da palavra. Mas também ocorrem os metaplasmos no uso comum da língua, como em certas pronúncias: advogado - adivogado ou adevogado; pneu - pineu.
} 
desvios. O que Haraway está propondo é que nós olhemos para essas histórias com atenção para com elas aprendermos a conviver, coabitar, com espécies diferentes, com o devido respeito que as especificidades pedem. Aprender as histórias dos cachorros nos leva a respeitá-los, a ir além do amor incondicional. Aprendemos sobre suas características físicas e psicológicas e passamos a tratá-lo como um indivíduo que pertence a uma espécie diferente, com necessidades diferentes, e não apenas como um ser fofinho que irá me amar simplesmente porque lhe dou comida, banho e casa. A coabitação, a intersubjetividade entre diferentes espécies, requer que abandonemos antigos vícios de pensamento, que não olhemos mais para indivíduos dentro de tipologias monolíticas, mas através das múltiplas relações que os (e nos) constituem. É preciso uma cosmopolítica para as espécies companheiras.

\section{Cosmos}

O bestiário de tipos de relações, agências e marcações de tempo que formam as espécies companheiras, segundo Haraway, "superam a imaginação até mesmo dos cosmologistas mais barrocos" (HARAWAY, 2021, p. 15). Segundo Emanuele Coccia (2018), a filosofia tem na sua origem o questionamento sobre a natureza do mundo, em um discurso sobre a física e sobre o cosmos. Essa identificação entre natureza e cosmos significava fazer da natureza aquilo que se exprime em tudo o que é, e não um princípio separado; ao mesmo tempo, significava ver o mundo não como um conjunto lógico de todos os objetos ou a totalidade metafísica dos seres, mas "a força física que atravessa tudo o que se engendra e se transforma" (COCCIA, 2018, p. 23). No entanto, as cosmologias começaram a perder espaço na modernidade, justamente por causa do grande cisma que separou o que era objeto das ciências naturais do que era objeto das ciências humanas ou políticas, transformando a natureza em um objeto sem espírito. Não por nada o termo cosmos voltou a figurar com força nas filosofias contemporâneas que começaram a questionar esse divórcio e a apresentar uma visão crítica do discurso científico. A cosmotécnica de Yuk Hui, a cosmopolítica de Isabelle Stengers, o multinaturalismo de Viveiro de Castro, a política animal de Brian Massumi, a metafísica da mistura de Emanuele Coccia; todos eles trazem consigo a urgente necessidade de se olhar para o mundo ou mundos que habitamos. Podemos dizer que o trabalho de Haraway, que se inicia com esse novo manifesto, também entra nessa corrente do pensamento que se voltou para a cosmologia. 
Kósmos, em grego, significava literalmente algo "bem-ordenado, harmonioso"; o verbo kosmein significa, de modo geral, "dispor, preparar" 15 . Pitágoras foi o primeiro a usar o termo para se referir ao universo. Em Process and Reality, Whitehead apresenta um esquema de ideias cosmológicas, uma cosmologia na qual todos os tópicos particulares encontrem suas interconectividades. Para ele, um dos motivos de uma cosmologia completa é construir um sistema de ideias que coloque junto a estética, a moral e a religião com os conceitos das ciências naturais - o que já indica o caminho interdisciplinar e antifronteira de toda especulação cosmológica. E esse também não deixa de ser um projeto que se percebe na obra recente de Haraway e que ela introduz no seu manifesto. Por isso, ela não deixa de fora de suas histórias questões que vão da biologia à religião, da história do capitalismo à história evolutiva, do jornalismo à divulgação científica.

Em When Species Meet, ela afirma que uma abordagem através das espécies companheiras "precisa se engajar em uma cosmopolítica" (HARAWAY, 2008, p. 88, grifo da autora). Esse trabalho requer reconhecer que os modos de viver e morrer importam e que não há respostas vindas de um fora a pergunta sobre quais práticas historicamente situadas de vida e morte das multiespécies devem prosperar; é preciso dar as melhores respostas que viermos a saber. São práticas emergentes, atuantes, com os pés no chão. Mas também não significa recair nas práticas pré- e/ou pós-modernas (os cosmologistas barrocos e os carnavalescos pósmodernos) do vale tudo e do relativismo. Retomando Stengers, ela define a cosmopolítica como uma proibição tanto do sonho de uma solução única e final para todos os problemas, como a fantasia da comunicação transparente e inocente. A cosmopolítica é uma prática para continuar, para seguir com o problema, permanecer exposto às consequências de se enredar materialmente com tantos jogadores quanto possível (HARAWAY, 2008).

O que está em jogo nesse projeto, companheiro de tantas outras cosmologias atuais, é olhar para as relações concretas que se formam na história, na linguagem e no corpo. É preciso fugir das armadilhas abstratas, como defende Whitehead. A especulação filosófica na obra da autora a coloca em companhia dessa nova tendência nas ciências (naturais e humanas) de começar a pensar no mundo mais do que no sujeito. Não há mais um sujeito transcendental possuidor do saber, não há mais um Dasein construtor de mundos ${ }^{16}$. Há mundos habitados por

\footnotetext{
${ }^{15}$ Mais especificamente o termo também pode significar, "ordenar e arranjar [tropas para uma batalha]", "pôr [um exército] em ordem", assim como "estabelecer [um governo ou regime]" ou "enfeitar, adornar, equipar, vestir".

${ }^{16} \mathrm{~A}$ ontologia heideggeriana é com certeza um dos exemplos mais clássicos do discurso humanista moderno que está sendo colocado em cheque na atualidade. Para Heidegger, o ser humano era o único ser capaz de criar 
diferentes espécies, mundos criados e cocriados por cada uma dessas espécies, das mais simples às mais complexas, e por todas elas em conjuntos, em relações sempre vivas, que não cessam de acontecer. Por isso, suas espécies companheiras já apontam para a necessidade de pensar novas formas de relações, de relacionamentos. "Fazer parentescos" significa pensar essas relações para além das tradicionais formas de agrupamentos. Em inglês, "making kin", fazer parentesco, mas "relatedness", a expressão em inglês usada por Whitehead para se referir à categoria da relação, também significa "parentesco". Mudar o olhar das qualidades preconcebidas e estáticas para as relações constantes e inacabadas é pensar numa cosmopolítica em que relações entre espécies diferentes importam, no discurso e na carne.

\section{REFERÊNCIAS}

BURCH, James. Beloved robot dogs honored in funeral ceremony. [S. l.]: 2018. Disponível em: https://www.nationalgeographic.com/travel/article/in-japan-a-buddhist-funeral-servicefor-robot-dogs. Acesso em: 03 out. 2021.

CHAMBERS, Robert. Judicial combat between a man and a dog. [S. l., s. d.]. Disponível em: http://www.thebookofdays.com/months/oct/8.htm. Acessado em: 05 jun. 2020.

COCCIA, Emanuele. A vida das plantas: Uma metafísica da mistura. Trad. Fernando Scheibe. Florianópolis: Cultura e Barbárie, 2018.

HARAWAY, Donna. O manifesto das espécies companheiras: cachorros, pessoas e alteridade significativa. Trad. Pê Moreira. Rio de Janeiro: Bazar do Tempo, 2021.

HARAWAY, Donna. When Species Meet. Minneapolis: University of Minnesota Press, 2008.

LATOUR, Bruno. Jamais fomos modernos. Trad. Carlos Irineu da Costa. São Paulo: Editora 34, 2019.

MASSUMI, Brian. O que os animais nos ensinam sobre política. Trad. Francisco Trento e Fernanda Mello. São Paulo: n-1 edições, 2017.

WHITEHEAD, Alfred North. A ciência e o mundo moderno. Trad. Hermann Herbert Watzlawickj. São Paulo: Paulus, 2006.

WHITEHEAD, Alfred North. Process and Reality: an Essay in Cosmology [Corrected edition]. New York: The Free Press, 1985.

mundos, sendo assim superior aos animais, vegetais e pedras. Mas hoje podemos bem ver que, antes de tudo, o ser humano é o único ser que destrói mundos e que essa precedência dele sobre outros seres não passa de um mito bem construído e pegajoso, que ajudou a fundamentar as mais terríveis e violentas práticas que foram consagradas como inevitáveis resultados do progresso. 
Resenha submetida em: 21 out. 2021. Aceita para publicação em: 22 out. 2021. DOI: https://dx.doi.org/10.22456/2238-8915.119468 